\section{Natriuretisch wirksame Substanzen}

Helga Peter

Marburg, Deutschland

\section{Englischer Begriff}

natriuretic agents

\section{Definition}

Siehe $>$,Mineralstoffwechsel und Volumenregulation“. 